\title{
BARRIERS TO GENE FLOW \\ IN NATURAL POPULATIONS OF GRASSHOPPERS \\ II. MAINTENANCE OF NARROW HYBRID-ZONES \\ BETWEEN MORPHS OF ARPHIA CONSPERSA \\ ON BLACK MESA, COLORADO ${ }^{1}$
}

\section{By Rober'T B. Willey and Ruth L. Willey ${ }^{2}$}

In the previous publication of this series (Willey and Willey, 1967), we described the zoogeography of Arphia conspersa on the two sides of the Black Canyon of the Gunnison River in southwestern Colorado. North of the canyon the populations are monochromatic for red-orange wing color and south of the canyon the populations show a steep cline from west to east culminating in nearly $100 \%$ yellow-winged demes even though they often are less than one aerial mile from the orange-winged populations on the North Rim. We concluded that the sides of the canyon were an effective barrier to gene flow between the two rim populations and that the sedentary behavior and social cohesiveness of the adults (Willey and Willey, I967 and 1969) probably slowed down lateral gene diffusion between the nearly adjacent demes of the South Rim.

We have completed a preliminary survey of a narrow hybrid-zone on Black Mesa, an adjacent area which we previously have discussed briefly (Willey and Willey, 1967). The barriers seem to be related to suitable habitat and, in this case, we hope to show that the mixed demes are subject to periodic extermination, and perhaps are maintained as a hybrid-zone by reinvasion from the neighboring monochromatic populations.

\section{Methods}

The census method is that of Willey and Willey ( 1967 ). Briefly, we walked in a non-repeating spatial pattern through the habitat and scored each insect as it flew up as either orange or yellow. An effort was made to count IOO individuals in each contiguous deme (200 preferably), but counts as low as IO are reported in the protocol (Fig. I and 2). Nearly all the populations on the mesa were censused at least once during the six years of study; several were censused as many as ten times. If we felt the population could withstand

\footnotetext{
${ }^{1}$ Research was based at the Rocky Mountain Biological Laboratory, Crested Butte, Colorado; and X Lazy F Ranch, Crawford, Colorado.

${ }^{2}$ Address of the co-authors: Department of Biological Sciences, University of Illinois at Chicago Circle, Chicago 60680.

Manuscript received by the editor January 18, 1972
} 


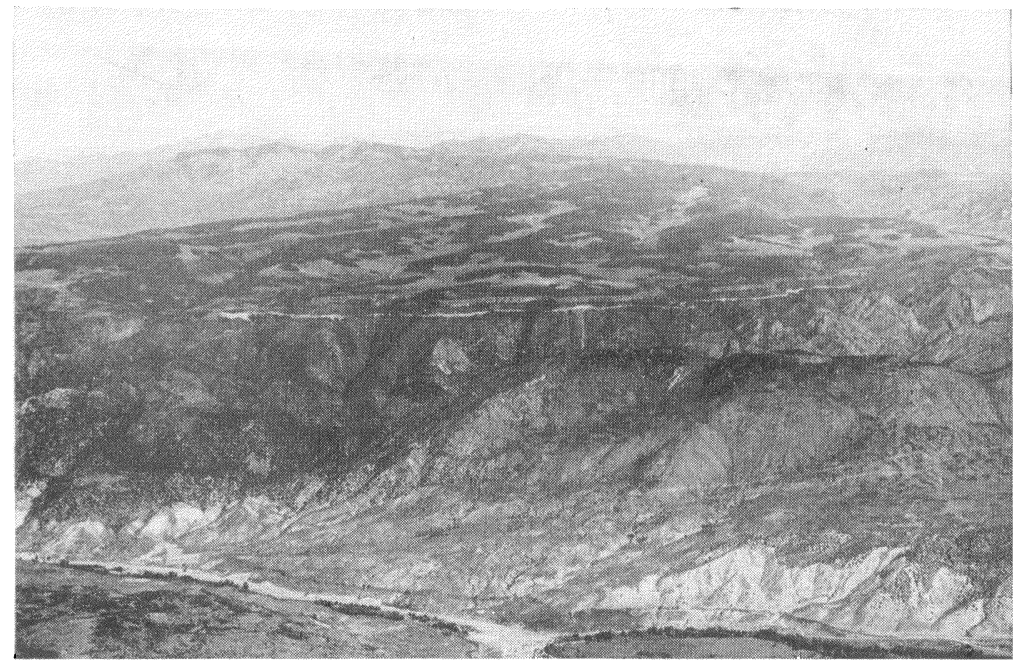

Plate 1. Oblique aerial view of Black Mesa from 30 miles south and 13,000 ft elevation, 15 September 1970. Route 92 (white line) marks the south edge of the mesa-top. Black Canyon is hidden behind Cimarron Hill and Fitzpatrick Mesa.

the predation, we sampled it, capturing 50 individuals in a random manner for more careful analysis and as specimens for future reference. A mark-recapture program on two adjacent zoogeographically strategic populations served as a check on census results and for analysis of individual movements during the adult period of the life cycle (Willey et al., in preparation). In 1970, total capture, character scoring and release were instituted, because of the low population level in that year. The following United States Geological Survey 7-I/2-minute Topographic maps were used for the survey, plates and figure-codes: Big Soap Park, Cathedral Peak, Cimarron, Crawford, Curecanti Needle, Little Soap Park, Sapinero, and X Lazy F Ranch, extending from $107^{\circ} 37^{\prime} 30^{\prime \prime}$ West and $38^{\circ} 37^{\prime} 30^{\prime \prime}$ North to $107^{\circ}{ }_{15} 5^{\prime}$ West Longitude and $38^{\circ} 22^{\prime} 30^{\prime \prime}$ North Latitude.

\section{ObSERVATIONS}

Black Mesa. This mesa is a well-defined plateau capped by volcanic rocks, principally andesitic breccias and rhyolitic welded tuffs of Oligocene age (Hansen, 197., and pers. comm.). It slopes upward from 9,000 $\mathrm{ft}$ on the southern rim to over II,000 $\mathrm{ft}$ at the northeastern end. Its southern rim forms part of the North Rim of the 
Black Canyon of the Gunnison River. This area is approximately 35 square miles and the mesa top stands 1000 to $2000 \mathrm{ft}$ above the surrounding valleys. Intermittent streams dissect the surface into four major north-south gulches draining into the Gunnison River and a major gulch drains each of the east and west sides of the mesa (Plates I and 2). Private ranches make up about 10\% of the area; IO\% is the Black Mesa Experimental Forest and Range, administered jointly by the United States Forest Service and Colorado State University at Fort Collins; the rest is in the Gunnison National Forest.

According to William Knott, a lifelong resident and forest ranger, the phytotopography of the mesa has not changed since settlement in I880, except that the common dandelion (Taraxacum officinale) was not present until 1920. Boundaries of grasslands and forested tracts are largely unchanged, except for the results of the Indian Wars in $1870-80$ during which several extensive forest tracts were burned by the Indians as a "scorched earth" policy. These burned areas and a few aspen groves with burned or sawed spruce stumps are easily distinguished from the virgin forests. The Indians used the mesa primarily as a hunting ground during the summer and several localities have numerous a tifacts scattered over the surface as evidence of repeated summer encampments.

Although the United States Geological Survey Topographic Maps were made from aerial photographs taken in 1955, the boundaries of chaparral, forest, and grasslands are accurate to minute detail even at the time of this writing (197I). The only changes are a small acreage of timber sales, construction of the Morrow Point and Blue Mesa Dams and Reservoirs within the Black Canyon itself, and the clearing for high tension power lines across the southwest corner of the Mesa.

The major forest component is Engelmann spruce (Picea engelmanni), alpine fir (Abies lasiocarpa) and quaking aspen (Populus tremuloides) in mixed or monotypic stands (Tietjen et al., 1967). Upland meadows, which are the primary habitats for Arphia, contain the bunch grasses Festuca thurberi, F. idahoensis and Stipa lettermani plus the forbs Geranium fremontii, Chrysopsis villosa, Erigeron macranthus, Lathyrus leucanthus, Agoseris spp. and the shrubs Chrysothamnus parryi and Potentilla fruticosa as the dominant plants in terms of herbage production (Paulsen, 1969). As can be seen from the map (Plate 2), the grasslands follow the drainages and were probably maintained as grasslands by the activities of the once 
numerous beaver. The forests form a barrier between each drainage. There are many upland meadows surrounded by forest forming a natural system of isolated habitats for grassland-dependent animal species such as Arphia conspersa. Below $9300 \mathrm{ft}$ elevation, we have determined that sage brush (Artemesia tridentata) becomes a dominant shrub and mixed with oak brush (Quercus gambellii), serviceberry (Amelanchier pumila), mountain mahogany (Cercocarpus montanus) and chokecherry (Prunus melanocarpa) form a dense chaparral on the edges and slopes around the mesa.

The climate is subalpine with heavy and continuous snow cover 5 to $6 \mathrm{ft}$ deep, usually from November through April (William Knott, weather station records and personal communication). Annual precipitation is quite variable; $\bar{X}$ from 1956 to $197 \mathrm{I}$ is 29.7 inches (S.D. $=6.6$ ), two-thirds falling as snow. The snow pack is variable in length; $\bar{X}$ from 1956 to $197 \mathrm{I}$ is 203 days (S.D. $=$ I 7.5). Insolation is high during May, June, and July with our Belfort pyrheliograph reading as high as $\mathrm{I} .6 \mathrm{cal} / \mathrm{cm}^{2} / \mathrm{min}$. Air temperatures during the summer months range from freezing at night to $25^{\circ} \mathrm{C}$ during the day. The area is subject to unseasonal snowstorms, periods of heavy rainfall and alternating saturated and dried-out soil. For example, on 26 June 1969, there was a wet snowfall of 6 to 12 inches. On 12 October 1969, a wet snowfall of 24 inches followed a week of heavy rains which saturated the soil. This snowfall formed the basis for a continuous dense snowpack above the $9000 \mathrm{ft}$ level until i5 May 1970. This early and continuous snowpack (2 16 days), just within one standard deviation, and long water saturation of the soil was unique in the memory of William Knott, whose family has kept precipitation and temperature records on the mesa since 1905. The snow pack of 1970-7 I was equally long, but started as a dry, cold snowfall. Again on 12 June 1970, there was a snowfall of 14 inches, which melted within a couple days. However, the snowpack records of the climatological station show that these last two winters were not the longest packs on record; that of 1956-57 lasted 247 days until i7 June and was equivalent to 30 inches of liquid water on 12 April. That year also was the wettest on record since 1905, 48 inches of precipitation (William Knott, personal communication). The effect on Arphia populations is unknown, since we began our studies in 1964. The vagaries of climatic conditions of this high plateau may be an important factor in the maintenance of steep polymorph clines in the $A$. conspersa populations. 
Arphia conspersa. For a full discussion of the life history and behavior of this oedipodine species, refer to our previous papers (Willey and Willey, 1967 and 1969). The species is spring-brooded with the nymphs (hoppers) overwintering during the third or fourth instar. The populations seem to be formed of loosely interacting social colonies which tends to reduce vagility. Their habitat preference seems to be a short narrow-leaved grassland with enough bare ground for courtship. Their altitudinal limit depends on slope and exposure and not yet understood limiting factors, but is between 9700-10,300 $\mathrm{ft}$ at the latitude of Black Mesa $\left(38^{\circ} 30^{\prime} \pm 7^{\prime} 30^{\prime \prime} \mathrm{N}\right.$.). The species is seldom found in dense tall-grass meadow, thick aspen or spruce-fir forest, dense chaparral or in irrigated pastures. Nor is it likely to be found on extensive bare rock or freshly disturbed areas. It seems to prefer seral edges and, despite its apparent lack of vagility, seems to be an opportunistic species, often appearing in regrown road cuts and chained (cleared) chaparral/grasslands within 5 years if established adjacent populations are available (Locality \#6ob, from Buckhorn Gulch \# 51a). However, Alexander and Hilliard (1969) list this species as a non-adventive species, seldom occurring in zones where it is not resident as nymphs, e.g., alpine zones and the timberline ecotone.

Zoogeography. Plate 3 shows the location and graphed wing-color proportions of each major deme on and adjacent to Black Mesa. Figure $\mathrm{I}$ is the protocol of each deme. We must emphasize that the proportions refer only to phenotypes, since the genetic analysis is still under investigation. Nevertheless, it is striking that phenotype proportions are quite similar within a gulch and may differ by $25 \%$ from the adjacent gulch. From the west, the only possible path of invasion to the mesa top is along the slopes of Long Gulch on the southwest or up Crystal Creek on the northwest. The nearest nearly I00\% orange-winged population is \# 52 (a) [Fig. 2] which is separated from the nearest Long Gulch demes (60\% orange-winged) by a virgin spruce-fir forest only one-half mile thick. Northward, the nearest Crystal Creek deme is \# 25 on the $9200 \mathrm{ft}$ contour. The passage onto Black Mesa rises to IO,500 on Powell Ridge and is, from all appearances, a suitable meadow and cut-over forest habitat, but presently that area is uninhabited by Arphia.

Between Long Gulch and Mesa Creek are thin strips of aspenspruce forest (some of which were lumbered 30-40 years ago) and very dense growths of Festuca thurberi. This latter is such a sufficient barrier that demes \#53a (the Mounds) and \#53b (the Forks) maintain proportions of $35-40 \%$ yellow and $60-75 \%$ yellow re- 
spectively, even though they are only one-half mile apart. These demes were intensively studied during I968-7 I by mark-recapture methods (Willey et al., in preparation) and no interchange was noted nor were any individuals found in the interspace. This patchiness of habitat utilization is characteristic of the Black Mesa demes. Figure $I$ is an accurate appraisal of the number of demes we were able to find on Black Mesa during eight years of study. From Mesa Creek eastward, a slight drop in average proportions is seen in Corral Gulch and then a sudden drop to $1 \%-4 \%$ in Myers Gulch. This phenotypic cline is two miles wide and there are several grassland corridors between the gulches through which gene flow could be accomplished.

We have analyzed by census, line transect, and sampling those demes and subdemes which occur in the trans-mesa corridors. These are best exemplified by \#54a, and b in one series (Experimental Pastures \# 5 and 6) and \# 54c, 54d, and 55a (the Transect). It is noteworthy that the corridor demes are, among themselves, a cohesive unit and, instead of showing a gradual cline from low yellow in the west to high yellow in the east, the break is between the easternmost corridor demes and the adajacent Myers Gulch deme. This may be the result of a zone of uninhabited grassland on the western portion of Myers Gulch, and the only demes we have found in the gulch are those shown in Plate 3 on the eastern side (\# 45c, 55b, 64a, and $64 \mathrm{~b}$ ).

Several peculiar relationships are indicated by Figs. I and 2. Although the major demes seem relatively stable in wing-color proportions, the smaller subdemes of the trans-mesa corridors differ in proportions from one census to another. For example, Pasture 6 (\# 54b) varied from $9 \%$ to $34 \%$ orange over three years. There is no pattern in this variation, and the total numbers are nearly the same for each census. There is no geographic pattern (geographic subdeme records are in Fig. 2), nor is there a pattern of morning and afternoon differences in the censuses. On 29 June 1968, a morning census showed a concentration of six orange males in one area of \#54b. These males could not be found on I July. The evidence suggests a transitory clustering of orange individuals in small areas which could skew censuses drastically if a group is missed, or if there is a single case of differential predation. However, a mapping program on the "Mounds" (\#53a) disclosed no difference in the dispersion pattern of distribution among any of the phenotype classes (Willey et al., in preparation). 


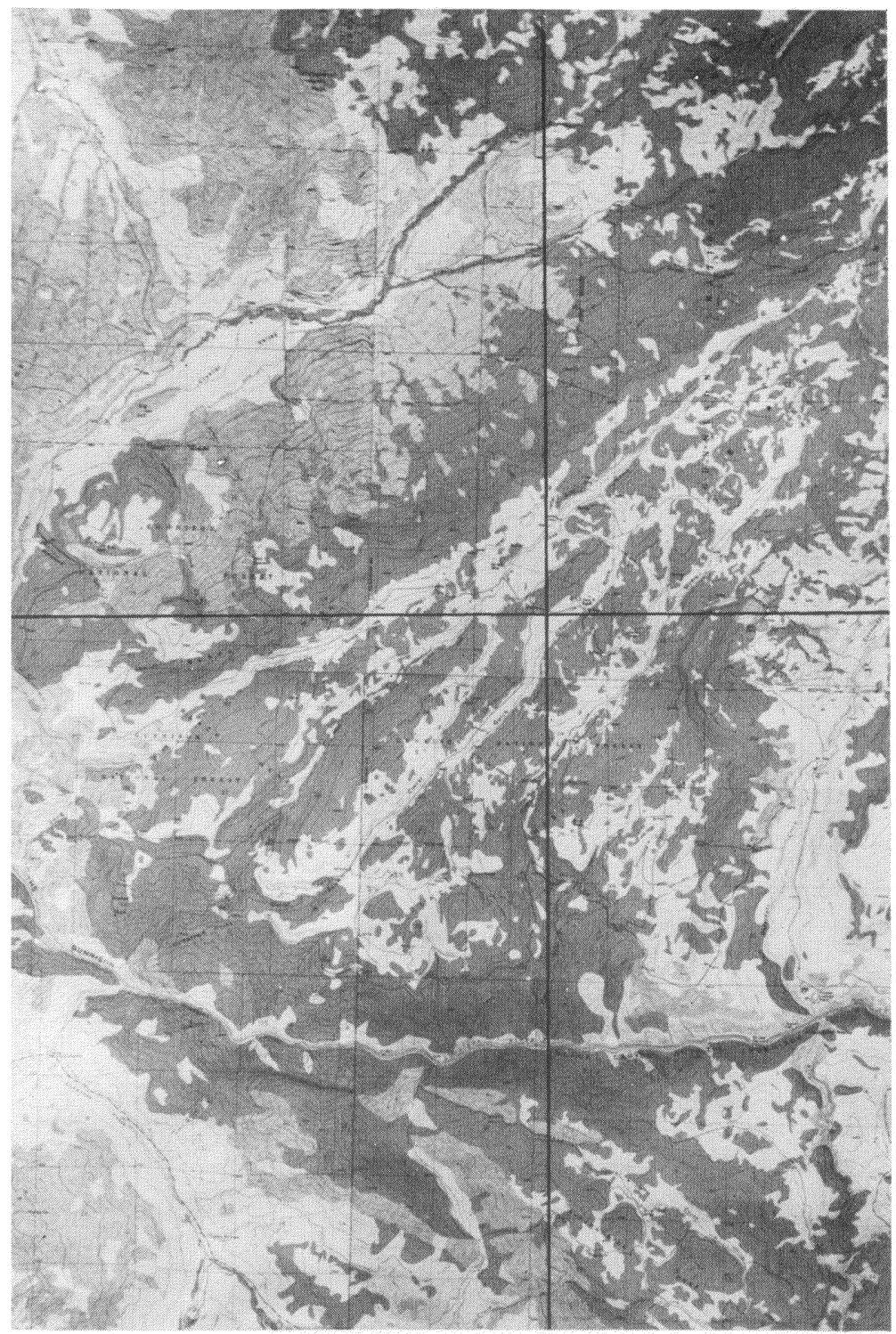

Plate 2. Collage of U. S. Geological Survey $71 / 2$ Minutz Topographic Maps (Cathedral Peak, Cimarron, Curecanti Needle and X Lazy F Ranch), showing Black Mesa and environs. Compare with Pl. 3 on the facing page to see the relationships between $A$. conspersa deme structure and phytotopography. 


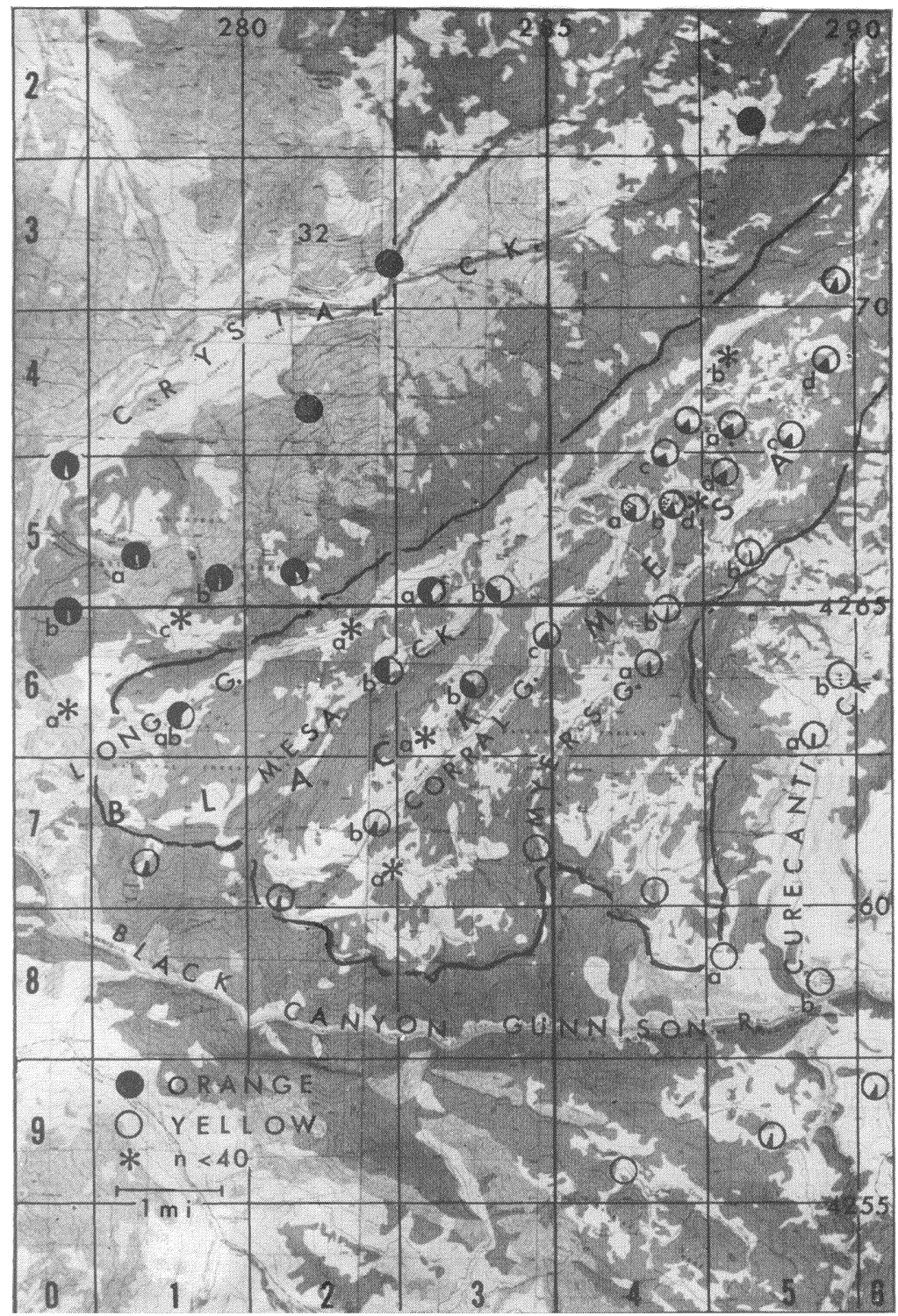

Plate 3. Same collage as in Pl. 2 showing most of the censused localities nd their relative proportions. For explanation see text, page 348 . 
The "Transect" (\#44a, 54c, 55a) also exhibits this clustering phenomenon. In this case, we were able to map the orange-winged clusters in 1968 and again in 1969. They were present in the same positions both years. We then ran two transects, each I mile long, through the area (Hill, I969, unpublished data) to ascertain any dispersion from these clusters. None seemed to occur. Uniformly, the clusters of orange-winged insects occurred on mounded elevations of pasture with Festuca thurberi providing slightly greater cover than in the areas more densely populated with yellow-winged individuals. These results indicated three possible causes: I) the orange-winged phenotype has some pleimorphic preference for denser habitat, 2) there is a low vagility of individuals during the entire life span and they seldom wander far from the original hatching point, or 3 ) the phenotypes have reached some level of behavioral or ecological separation. We currently are investigating the clustering patterns of these populations.

It is clear that the only invasion route for yellow-winged phenotypes is from southern Curecanti Canyon and from the slopes of the South Rim of the mesa via the major gulches. All other avenues are blocked by the forest. We should emphasize the habitat type, the size, and the elevation of the northernmost demes on the mesa. Number $45 \mathrm{~b}$ is a tiny deme of 8 to 20 individuals which survives around an old sawdust pile - all that remains of a lumber mill. A few more individuals can be found in an adjacent burned-over and logged area, but this area is primarily an early sere characterized by broadleaved plants, brambles, and few grasses. Number 35 is slightly larger and has several small subdemes. The deme inhabits a cleared private pasture at $10,300 \mathrm{ft}$, which enjoys a southeastern exposure. The floral phenology is similar to that of areas $500 \mathrm{ft}$ lower. The "Burn Area" contains large subdemes $(\# 45 \mathrm{~d})$ which have colonized an extensive burned-over area. After 85 years, this soil still can support only scattered bushes (Ribes lacustre and Sambucus sp.) and small, sparse patches of Festuca idahoensis, F. thurberi, Stipa columbiana, $\mathcal{S}$. lettermani and Blepharoneuron tricholepis, which provide good though discontinuous habitat for $A$. conspersa. However, the floral phenology is much delayed over that in other habitats and indicates continuous snow cover until 15 May or later. Demes in higher altitudes farther north have been indicated in some years by sighting one or two males, a female, or hearing some crepitations. Whether these are founding colonies which succeed only for a year or two is not known. In two of these cases they were found in old 
lumber mill sites near sawdust heaps and in one case the male was found in an old homestead foundation.

In 1970, populations over the entire mesa above $9200 \mathrm{ft}$ crashed. In most areas, no Arphia could be found. In demes \#53a, b and $54 \mathrm{a}$, between 8 and $4 \mathrm{I}$ individuals were found in a total capture survey, about I to I5 percent of the expected population level. Of these, nearly one-half had blebs on the pronotum, an anomaly found in only $2 \%$ of normal populations. Lower altitude populations were very nearly normal in density and high counts were made of \# 50 , 5Ia, 82 and the North Rim of the Black Canyon National Monument (over 600), all occurring between 7700 and $9100 \mathrm{ft}$ elevation. Similar crashes in usually dense populations occurred 40 miles north at Gothic (9500 ft, Gunnison County), and Jack's Cabin Cut-Off ( $9000 \mathrm{ft}$, Gunnison County). On the other hand, we have noted and collected sufficient nymphs of $A$. conspersa (over 200 in several areas) in August and September, 1970, to convince us that the diapausing eggs of the 1969 adult brood were not adversely affected by the winter and hatched normally in the summer of 1970 .

In 197I, the populations were normal in abundance, though not as high in number as those of 1969 . The mark-recapture program on the Mounds (\#53a) showed a population of 400 , whereas in 1970 only I 5 adults were found. In September, I97I, only one nymph was found in this area, two nymphs in the Burn Area (\#45d, Ioo nymphs in 1970 ), and 16 nymphs in Pasture 5 (\#54a, 4I adults in 1970, over 200 adults in 1971). This small number of nymphs in 197 I indicates no recovery of the 1970 brood.

\section{Discussion}

Black Mesa is subject to severe vagaries of weather. Since the snow packs of 1969-70 and 1970-7 I were nearly the same length (216 and 215 days respectively), and the I97 I adult brood was only a little below normal in density, we think that conditions before the snowpack of 1969-70 or after it had melted probably caused the population crash of I970. These conditions could have been I) the snowfall of 26 June 1969, which may have killed hatching nymphs; 2) the wet snowfall and rains of early October, 1969, which could have harmed cold-immobilized nymphs; 3) the snowfall of 12 June 1970, which could have killed emerging adults, and 4) an undetected late freeze which could have decimated freeze-sensitive nymphs emerging from hibernation in May. The fact that half of the surviving adults had developmental anomalies, especially blebs on the pronotum, indicates some sort of post-dormancy damage. However, the 
specific causes for the widespread failure of the 1970 adult brood are still uncertain and probably were cumulative. In a simpler case, Ehrlich et al. (1972) have noted a similar series of extinctions of the butterfly Glaucopsyche lygdamus at these altitudes in this same general area which they prove was due to destruction of oviposition sites and larval food plants by the snowfall of 26 June 1969 .

Consequences of the failure of the $1970 A$. conspersa brood are the problem of subsequent recruitment and the entire question of the maintenance of the Black Mesa hybrid zone. It will be very instructive to follow the reestablishment of the Arphia demes from the few surviving centers of the 1970 brood, from the off-mesa populations, and perhaps from the odd-year brood. Certain proportion discrepancies, such as those shown by \# 53b (the Forks), \# $72 \mathrm{~b}$ (Corral Gulch), and \#45d(c) (southeast meadow of the Burn Area) seem related to alternate years. Since we have proved in the present results that the Black Mesa populations overwinter as egg and nymphs, there may be two genetically independent populations, one reaching adulthood on even-numbered years and one on odd years. However, further yearly censusing of strategic populations is necessary to determine the validity of this assumption and to determine the amount of temporal crossing-over by any non-diapausing individuals.

The narrowness of the Black Mesa hybrid-zone has puzzled us, but now it seems clear that periodic extermination of the mesa-top populations could afford a considerable setback to any extensive gene flow. Indeed, the presently inhabited portion of the mesa probably has been colonized by $A$. conspersa only within the past I 50 years since the beginning of the last climatic warming trend after the Neoglaciation (Remington, I968, p. 350; and Richmond, 1965) which probably had made most of the mesa-top uninhabitable. Any long term cooling trend resulting in increased precipitation, numbers of late frosts or snows, etc., could again cause the mesa to become an altitudinal barrier. It is also probable that the 1970 population crash is not a unique occurrence on the mesa, even during this present hypsothermal period.

If the present zoogeographic pattern of wing-color variation is the result of recent colonization, it is probably safe to assume that the connecting corridors and forest barriers are at least as old and we can describe original invasion patterns in terms of the present topography. However, with current pressures on the National Forest Service to release tracts for lumbering, the original proportions of vegetational associations, the climatic patterns and even the water-holding capacity 
of the mesa will be changed. It is well to have a baseline for evaluating the changes which will occur in the zoogeography of this zone of hybridization. It should be instructive to examine this area soon for evidence of other species- and morph-pairs in the process of hybridization, since climatic conditions and geography at present seem ideal for the development of a common "suture-zone" between species-pairs of diverse organisms (Remington, I968), especially between those which are spring-brooded, ground-inhabiting poikilotherms.

Conclusions

On Black Mesa, Colorado, the grasshopper Arphia conspersa exhibits a phenotypic cline in wing-color variation which separates I00\% orange-red demes from $100 \%$ yellow demes by two to five miles. The cline seems to be maintained by three factors at least: I) limited vagility of the individuals in a deme, 2) unsuitable habitat between the geographically discontinuous populations, and 3) periodic, virtually complete, exterminations of the hybrid demes by climatological catastrophes related to the fact that the mesa-top is at the altitudinal limit for the species.

\section{SUMMARY}

Arphia conspersa varies in wing color on Black Mesa in southwestern Colorado. The phenotypes exhibit an orderly but steep step-wise cline from $100 \%$ orange and red to $100 \%$ yellow over a distance of only two to five miles, ascertained by sight-census and mark-recapture methods over a period of eight years. Black Mesa slopes gradually from $9000 \mathrm{ft}$ elevation in the south to I I,OOO $\mathrm{ft}$ in the north. Since $A$. conspersa has successfully colonized only a few areas above I0,000 $\mathrm{ft}$, this also affords an opportunity to observe the ecology of a species at its altitudinal limit.

In 1970 , 50 demes which had been located on the mesa were virtually exterminated, probably by unseasonal weather conditions prior to and after a prolonged winter snow pack lasting more than 8 months. However, these high-altitude populations have a two-year life cycle with both eggs and nymphs overwintering. The alternateyear brood, which had over-wintered eggs in 1969-70, was unaffected and matured normally in I97I. Census of nymphs in the fall of I97 I indicated no recovery of the nearly exterminated brood. This catastrophe strongly suggests that maintenance of this narrow hybrid-zone depends not only on the barriers produced by unsuitable habitat, but also on periodic extermination of the mixed populations. It also indicates the survival value of a two-year life cycle at the altitudinal limits of a species. 


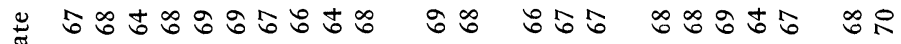

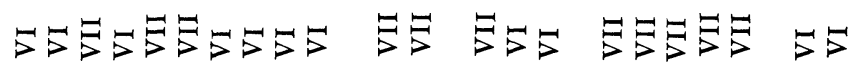

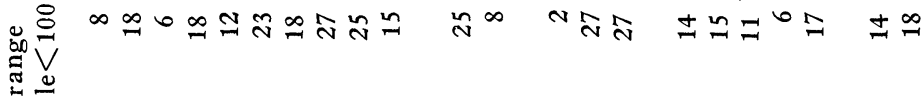

흘

பี

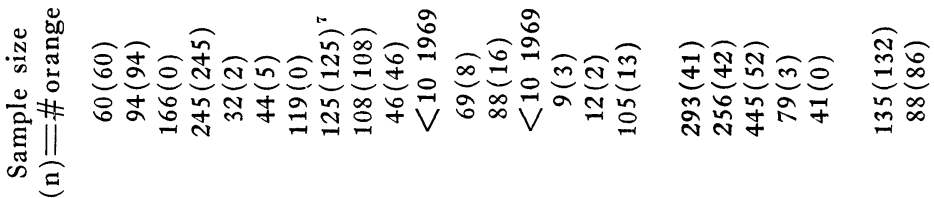

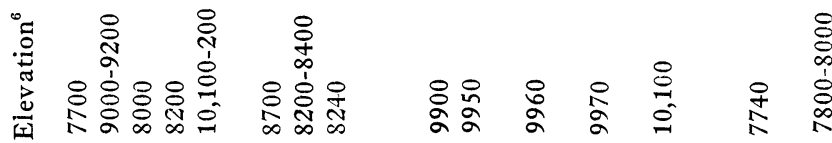

ت્ઞ

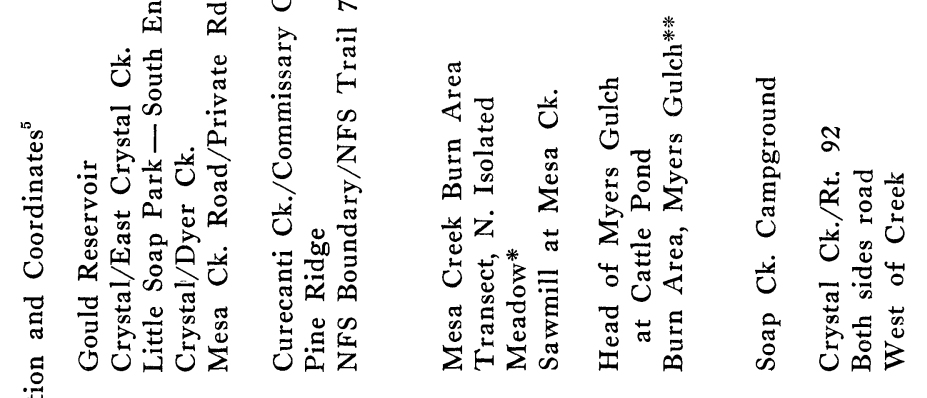

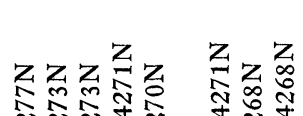

令令栾空

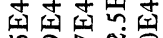

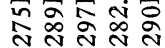

된 辛站

लำ

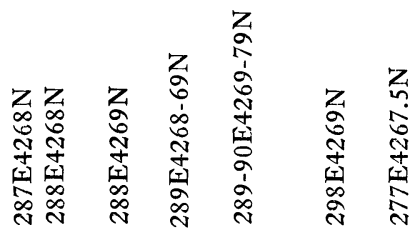

نँ

๙ิํํ요

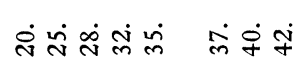

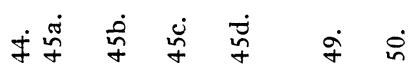




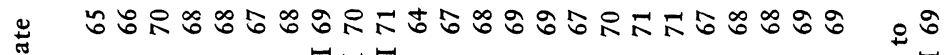

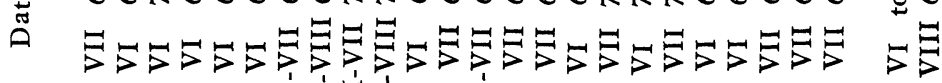

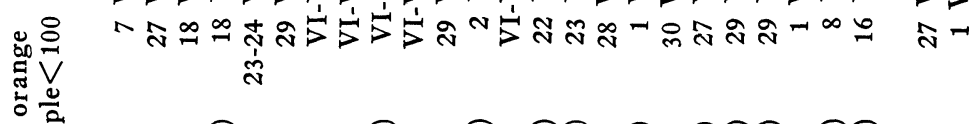

苞喏

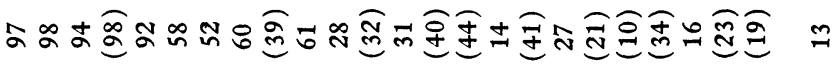

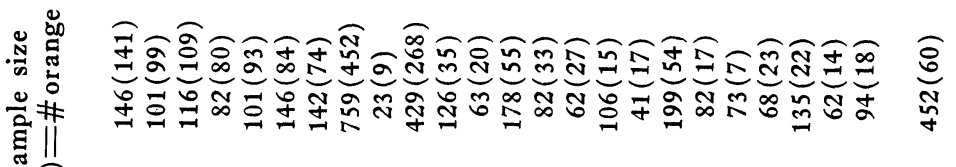

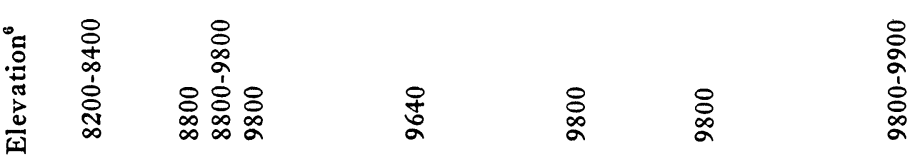

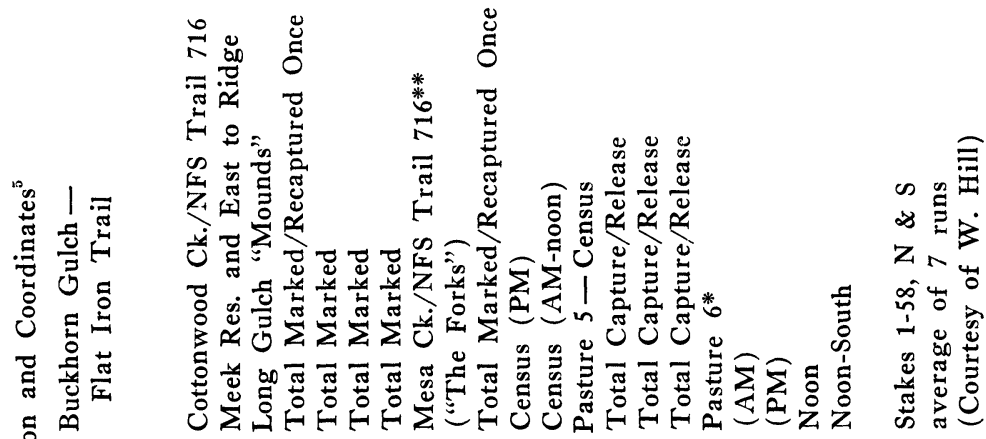

营

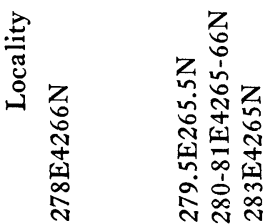

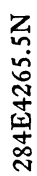

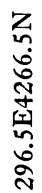

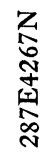

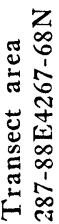

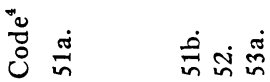

$\dot{\text { nิ }}$

离

$\dot{f}$

洜 
苛

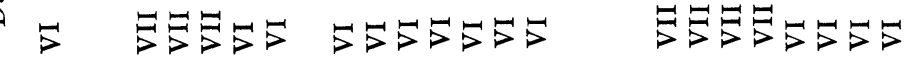

䒛

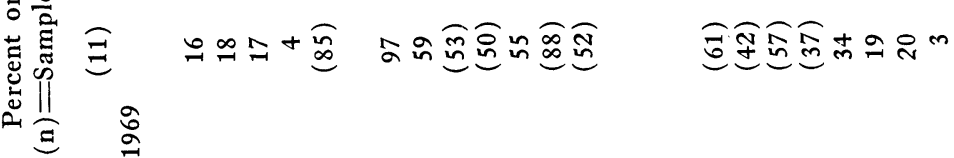

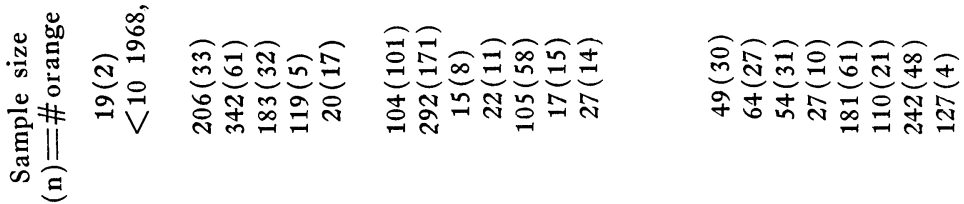

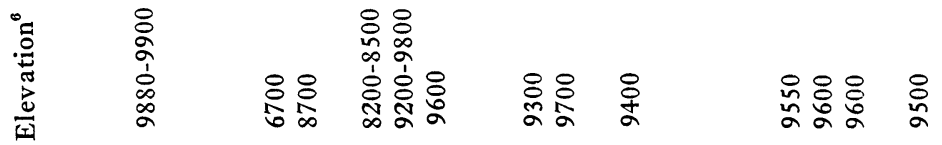

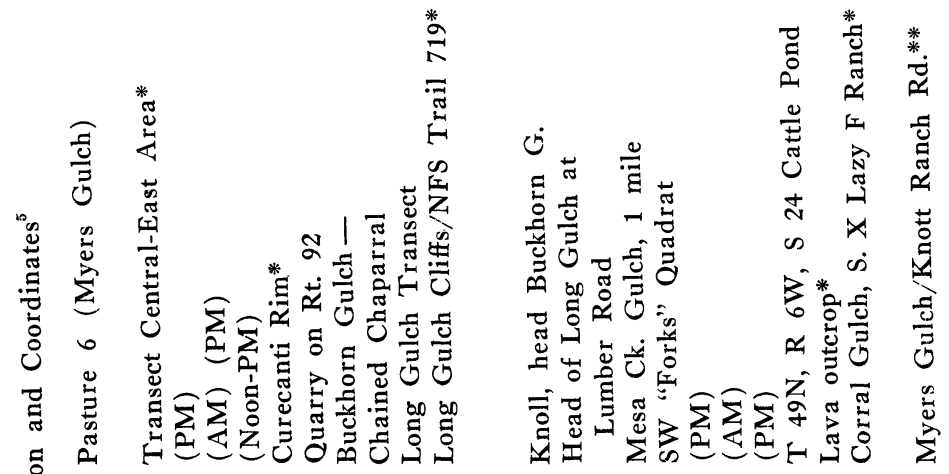

营

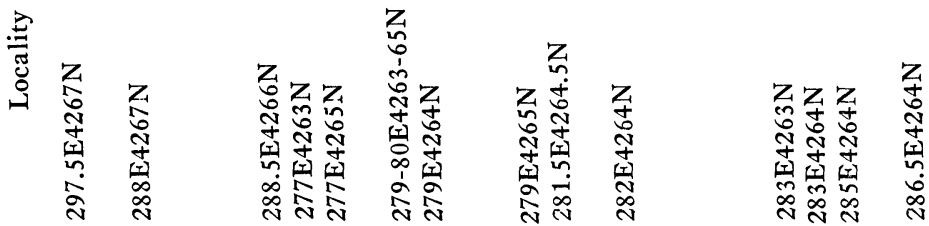

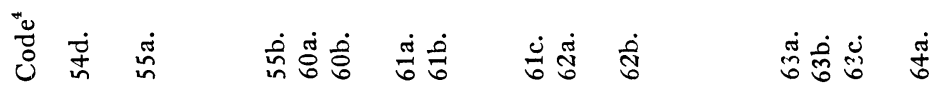




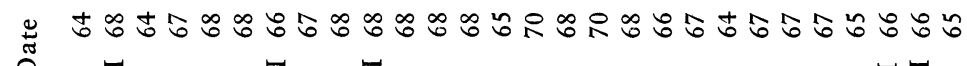

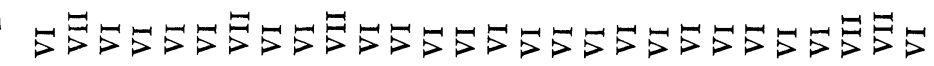

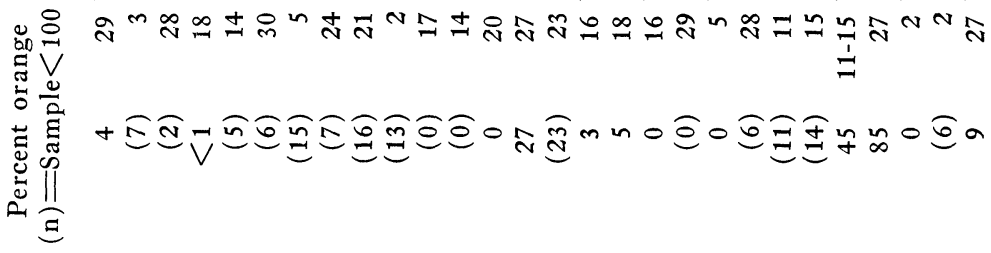

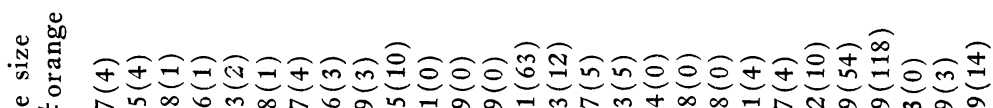

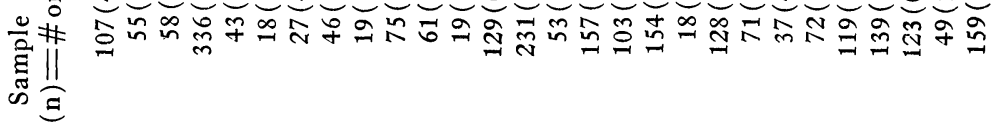

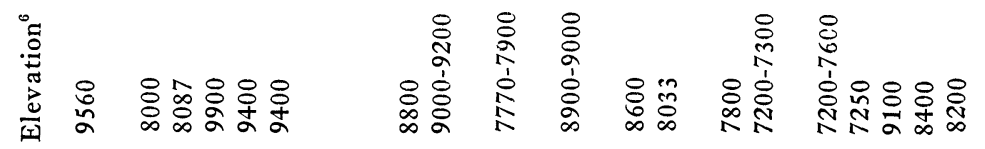

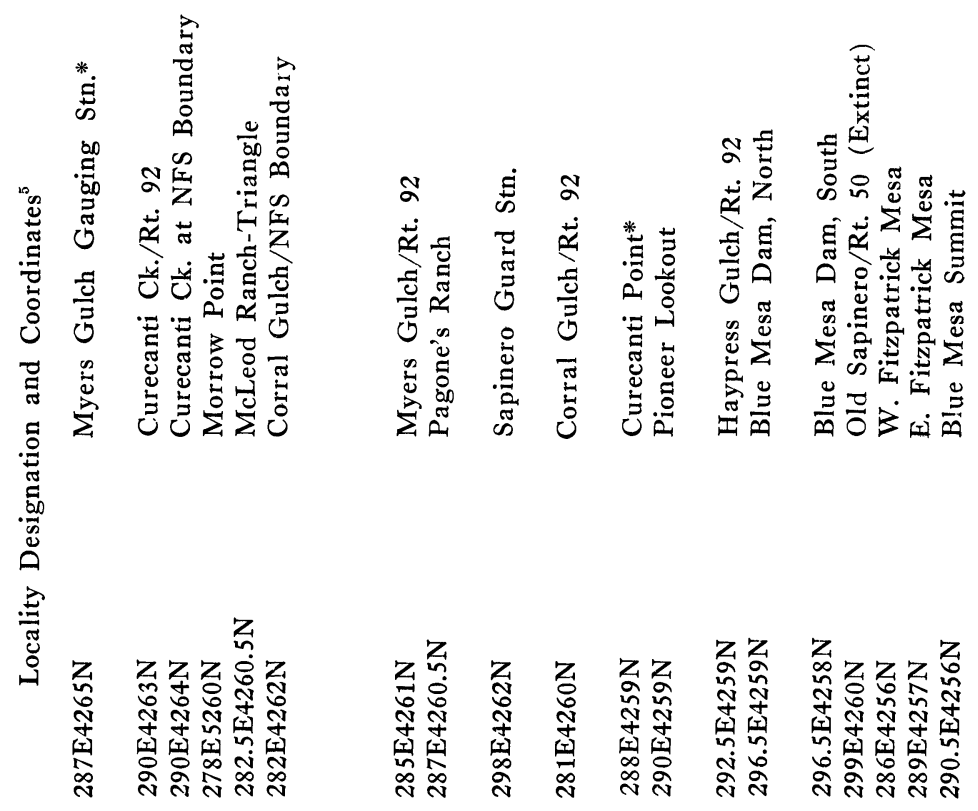

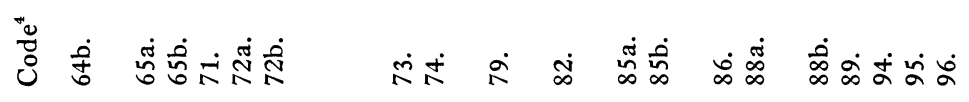


泀

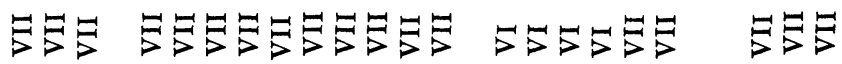

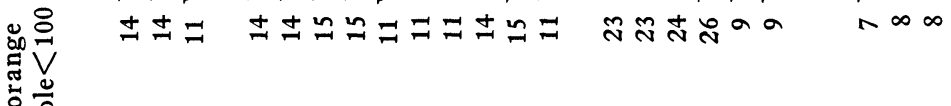

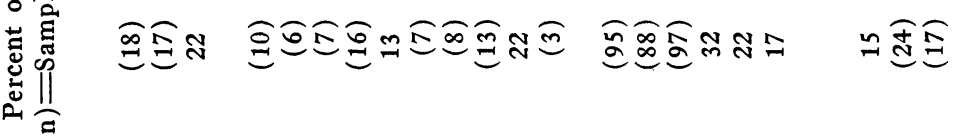

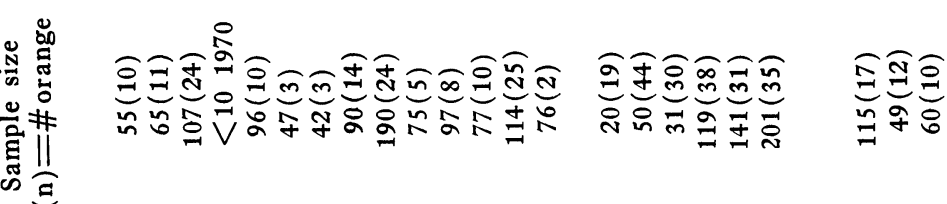

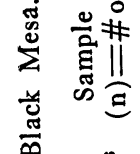

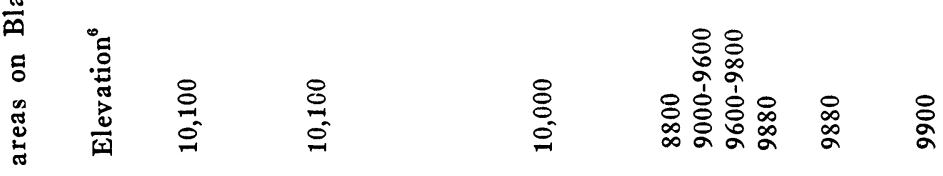

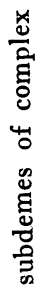




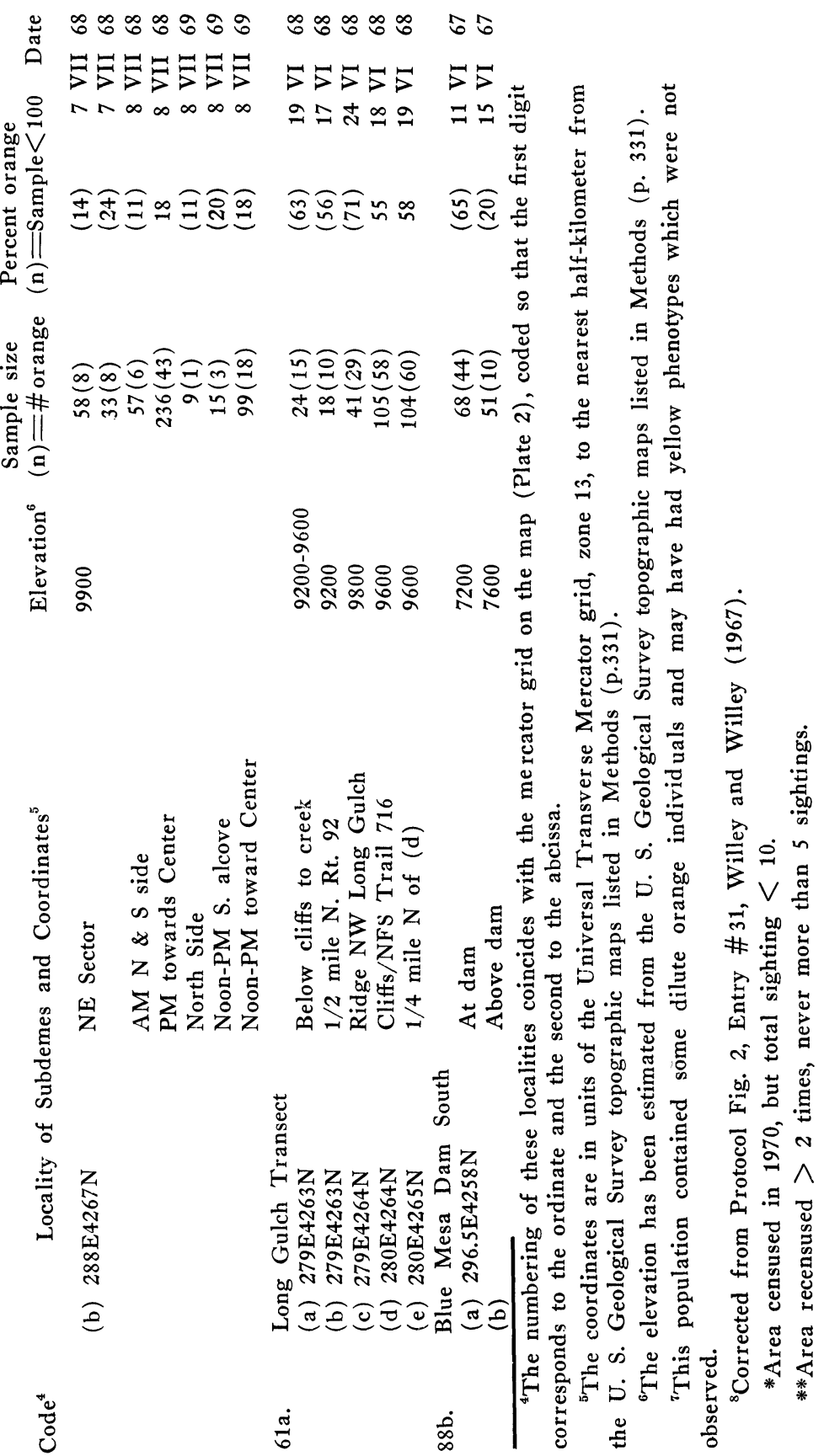




\section{Acknowledgements}

We acknowledge the help of our assistants, undergraduate research participants and volunteers in censusing: David Ballestas, David Borg, William Davis, Sharon Ginsburg, Anne Hill, Dennis Johns, James Karpus, Gordon and Muriel Kerr, Ellen Levy, Jaclin Lewbin, David Messenger, David Mucha, Gerald Mussgnug, Marianne Niedzlek, Ronald Outen, Frances Pivorunas, Joyce Redemsky (Mrs. Gregg Young), Wayne Schennum, Melvin Shemluck, Frank Slansky, Darelyn Weber (Mrs. Charles Handley), and David Werner. We thank Dr. Wallace Hansen, U.S. Geological Survey, Denver, for critically reading the manuscript; and Dr. Paul Ehrlich, Stanford University, for giving us a copy of the manuscript of Ehrlich et al. (1972). William Knott, Forestry Research Technician, Black Mesa Experimental Forest, has been most informative in the history, floristics, and climatology of Black Mesa. Dr. Raymond Price, former Director of the Rock Mountain Range Experiment Stations, allowed us to study populations in the experimental pastures and sent us reprints of their studies of the Black Mesa. We are grateful for the hospitality of George Klaitch, Manager of the X Lazy F Ranch, and the Colorado Synod of the Presbyterian Church for allowing us living and laboratory space at the ranch. The Forest Service land-use

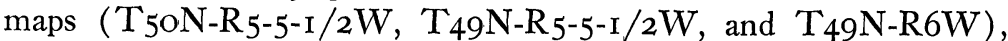
showing recent and projected timber sales, were supplied by R. M. Case, District Ranger. David Mucha's photographic assistance on Plates 2 and 3 is gratefully received. Mrs. Mary Grant retyped several revisions of this paper.

This study was partially supported by Grant GB-220I from the National Science Foundation, four grants from the University of Illinois Graduate Research Board, two grants from the Society of the Sigma Xi (r963 and 1968), National Science Foundation Predoctoral Fellowships to Wayne Schennum, and to James Karpus, and National Science Foundation Undergraduate Research Participation fellowships to William Davis, Sharon Ginsburg, William Hill, Gerald Mussgnug, Marianne Niedzlek, Ronald Outen, Melvin Shemluck and Joseph Wroblewski.

\section{Explanation of plates $2 \& 3$}

Plates 2 and 3 are quadrated by the Universal Transverse Mercator Grid (Zone 13) and in Pl. 3 every linear $2.5 \mathrm{~km}$ is numbered on the ordinate and the abscissa. The combined number (ordinate and abscissa respectively) produces the code number of each quadrat and its demes (Figs. 1 and 2). The lower case letters distinguish demes within a single quadrat. If a deme occurs on a grid line, the locality is numbered according to the code number 
of the quadrat to the south or west of the line (see quad. No. 32). Mercator lines $285 \mathrm{~km}$ East and $4265 \mathrm{~km}$ North are printed also on Pl. 2. The U.S. Geoglogical Topographic Maps were drawn from aerial photographs taken between 3 September and 27 September 1955. The light colored areas are grassland, grey is chaparral and dark is forest.

\section{Literature Cited}

Alexander, G. and J. R. Hilliard, Jr.

1969. Altitudinal and seasonal distribution of Orthoptera in the Rocky Mountains of Northern Colorado. Ecol. Monogr., 39: 385-431.

Ehrlich, P. R., D. E. Breedlove, P. F. Brussard, and M. A. Sharp

1972. Weather and the "regulation" of subalpine populations. Ecology, $53(1)$ : in press.

Hansen, W. R.

1971. Geologic map of the Black Canyon of the Gunnison River and vicinity, Western Colorado. U.S. Geol. Survey, Misc. Geol. Invest.: Map 1-584.

Paulsen, H. A., JR.

1969. Forage values on a mountain grassland-aspen range in western Colorado. J. Range Management, 22: 102-107.

Remington, C. L.

1968. Suture-zones of hybrid interaction between recently joined biotas. Evol. Biol. 2: 321-428.

Richmond, G. M.

1965. Glaciation of the Rocky Mountains. In Wright, H. E. and D. G. Frey (Editors), The Quaternary of the United States (Princeton, New Jersey: Princeton University Press, pp. 217-230).

Tietjen, H. P., C. H. Halvorson, P. L. Hegdal and A. M. Johnson

1967. 2, 4-D herbicide, vegetation, and pocket gopher relationships Black Mesa, Colorado. Ecology, 48: 634-643.

Willey, R. B. AND R. L. WILLEY

1967. Barriers to gene flow in natural populations of grasshoppers. I. The Black Canyon of the Gunnison River and Arphia conspersa. Psyche, 7.4: 42-57.

1969. Visual and acoustical social displays by the grasshopper Arphia conspersa (Orthoptera: Acrididae). Psyche, 76: 280-305.

Willey, R. B., G. Mussgnug, J. Wroblewsky and P. Wussow A study of the movement within a population of Arphia conspersa (Orthoptera: Acrididae). In Preparation. 

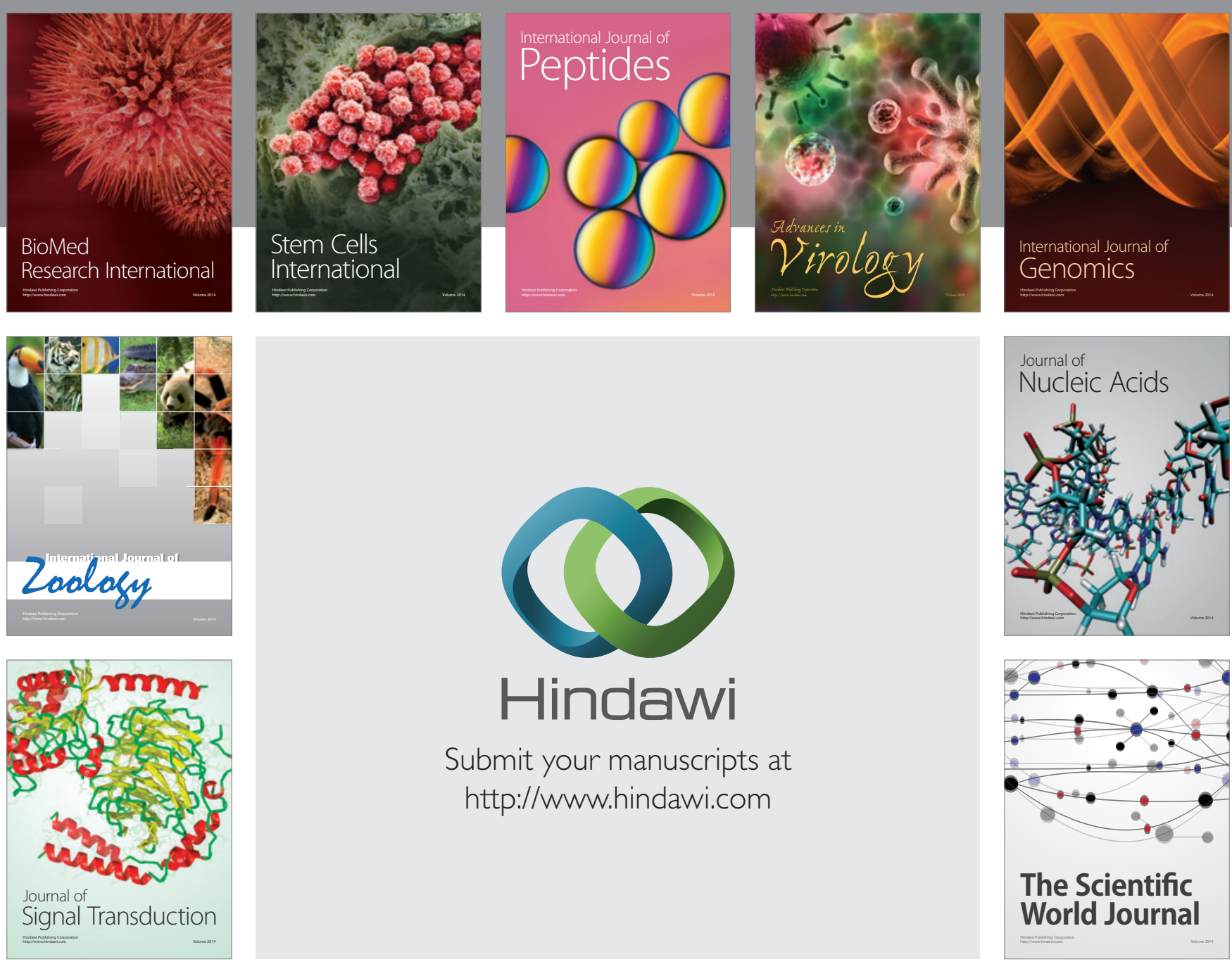

Submit your manuscripts at

http://www.hindawi.com
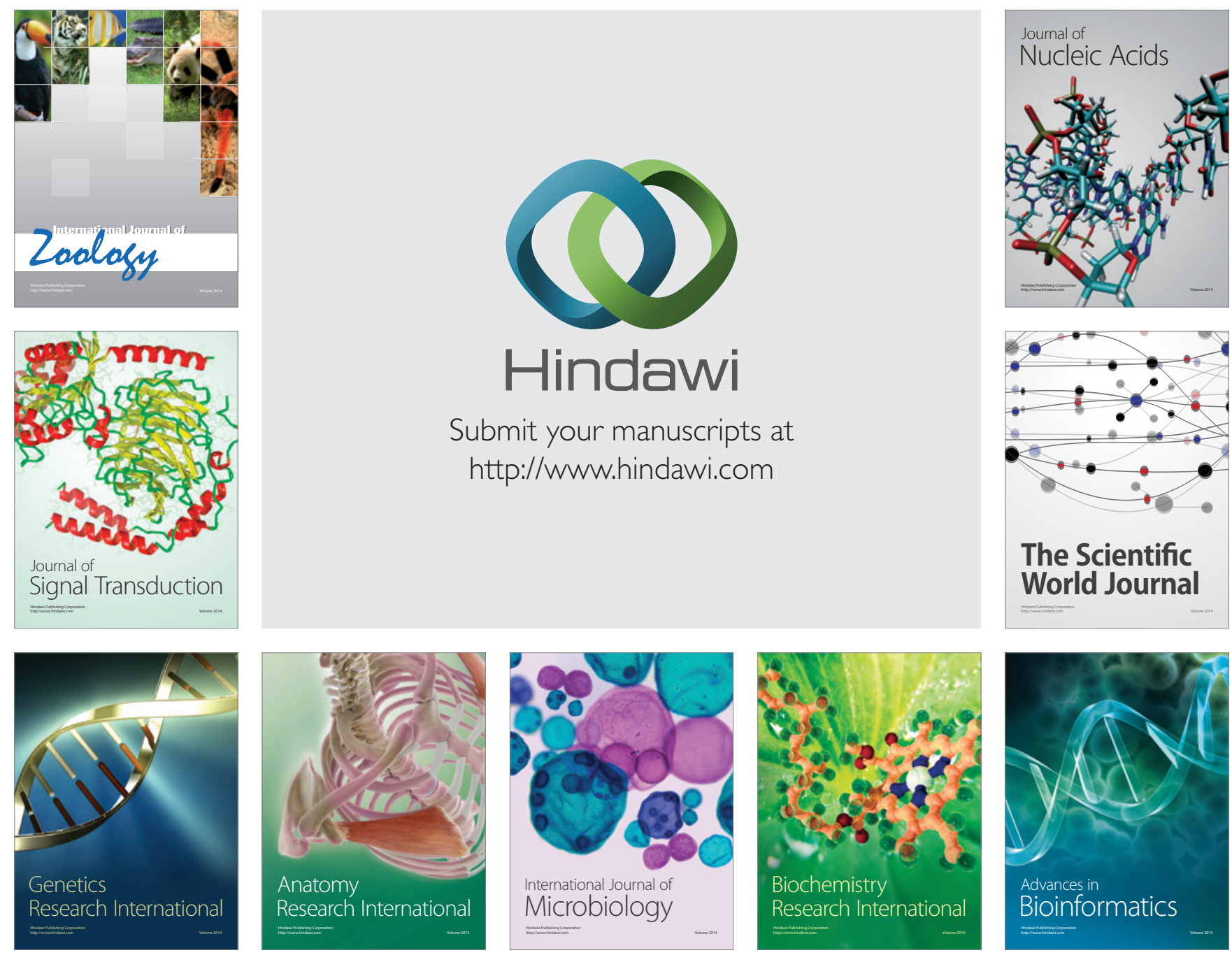

The Scientific World Journal
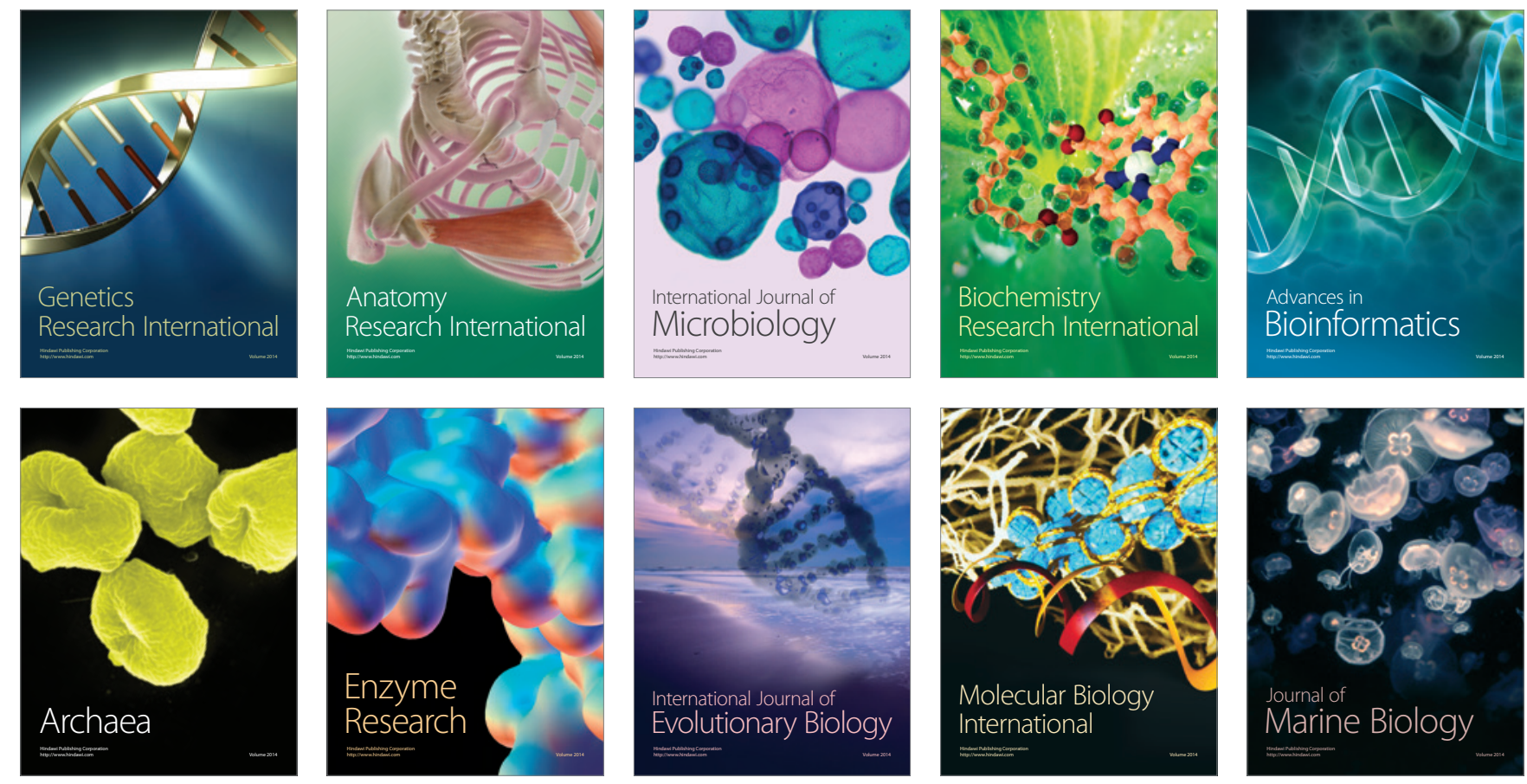